\title{
THE WORLD'S GLOBALIZATION AND GLOBAL MILITARIZATION
}

Todor Mirković

\section{Introduction}

Gobalization and militarization are two phenomena which attract special attention not only of public opinion but scientific and public workers as well. For a long time, the globalization was considered as military expansion, such as the endeavours of Alexander the Great, Roman and Ottoman empires' ambitions, British expansions, and Hitler's occupations. However, as a concept globalization is something quite different. Globalization of the modern time is understood as spreading new scientific and technological discoveries, economic, trade and transportation advances all around the world.

The notion of militarization should be distinguished from militarism. The militarization is a process of global character, while militarism is predominance of the military in the administration or policy of a state. As a global process, militarization is demonstrated through armament and disarmament, arms race and military trade, global threat of armed conflicts etc.

The impacts of the globalization and militarization upon the world's peace and development are exposed in quite different ways - the globalization in a productive, militarization in a destructive one.

In this article, globalization is deliberated in a rather large scale because it is, as a concept, relatively new and not so well understood among scientists, especially economic analysts. As a matter of fact, within the professional literature one can easily encounter quite different views. Proponents of globalization assert that it contributes to the development of both developed and developing world. On the other hand, the opponents think that globalization deepens the gap between developed and developing countries, promotes conditions that lead to unrest, conflicts and even to wars.

\section{Definition of globalization}

The term globalization came from the words globe (a representation of the shape of the earth, the earth itself, a planet), global (having a shape of a globe) ${ }^{1}$, and globalize (make it global). It usually begins with scientific discoveries and technological innovations at one place or by one scientist and spreads all around the world.

As a process, the globalization traces its history centuries behind, but as a concept it is of much earlier origin. According to Wikipedia, the free Encyclopaedia, one of the

\footnotetext{
* Prof. Dr. Todor Mirković, Col. Rtd.

${ }^{1}$ See, Webster's unified Dictionary and Encyclopedia New York, 1951, globalization is not listed, nor in the.
} 
earliest usages of the term as a noun was indicated in a 1930 publication titled "Towards New Education" where it denoted a holistic view of human experiences in education.

In the Webster's Unified Dictionary and Encyclopaedia, New York 1951 or in the American Heritage Dictionary of the English Language, Boston, 1973 the word globalization is not listed. In the Encyclopaedia Britannica 2005 - Deluxe Edition CD, globalization is listed as the process by which the experiences of everyday life foster a standardization of culture expression around the world.

In mass media and professional literature it is hard to find proper definition of the term. However, in the Wikipedia, one can find numerous definitions of globalization with the reference to their authors. It is worth to mention at least two of them. According to sociologists Martin Albrow and Elizabeth King, globalizations are "all those processes by which the peoples of the world are incorporated into a single society", while Swedish journalist Thomas Larsen in his book titled 'Race to the Top - the Red Story of Globalization' stated that globalization is "the process of world shrinkage, of distances getting shorter, things moving faster". The first definition refers more to the goal than to the clarification of the notion (the world to be incorporated into a single society) which can hardly be achieved, while the Thomas Larsen's definition expresses real sense of globalization.

Globalization, as we see it now, emerged with the Industrial, but dramatically intensified with the Technological Revolution. Some thinkers assert that globalization flourished with the fall of the Berlin Wall, when the iron and bamboos curtains were raised and free movements of peoples, ideas, goods and services were made possible.

\section{Globalization - Its sources and scope}

The centre of innovations and discoveries for a rather long time was in the Western Europe and spread through peripheries. During the Second Industrial Revolution it extended to the North America and in the course of the new Technological Revolution it is being spread to almost all other parts of the world.

According to Toffler(s) (Alvin and Heidi) ${ }^{2}$ contemporary civilization has passed through only two ages - agrarian and industrial. In the second half of the $20^{\text {th }}$ century it entered into the third - technological age. During the agrarian age, lasting a dozen of millenniums, there were no big discoveries and the ideas, news, and the like were kept within local boundaries. The Industrial Revolution, starting in the $17^{\text {th }}$ and being evaluated into Technological Revolution in the course of the $20^{\text {th }}$ century opened a new opportunity for new discoveries and faster globalization.

However, discoveries and inventions achieved in the Industrial Age were applied mostly within areas from which they emerged, that is, in the Western Europe and Northern America. Advances of such endeavours could hardly break the borders and penetrate into areas of Asia, Africa, Latin America and Oceania, that is, the developing world. With the advance of the Technological age, those borders were crossed much faster and much more easily.

\footnotetext{
${ }^{2}$ See, Alvin \& Heidi, The Third Wave, Bantam Book (USA), 1980.
} 


\section{New military technologies - Introduction into new Technological age}

In the Second World War, new military technologies played a crucial role in determining its outcome. Most of them were developed in the war period, some were developed in response to the lessons learned during the war, and some were in the beginning phase to be developed in the post-war period. During the war there were tremendous improvements in quality and efficiency of so-called standard weapons, such as artillery pieces and rockets, armoured vehicles, airplanes, ships and submarines. However, missiles and rocket technologies, nuclear weapons and electronic devices - radar, sonar, systems of weapons guidance, nuclear technology - traced the path to the new technological age.

Leaving the hot war, the contemporary world entered into a cold one. Two major allies in the hot war became potential enemies in the Cold War. Relying on the technological advances achieved in the Second World War, they continued and intensified research, development and production of new, more efficient and more deadly weapons. The arms race, especially in its horizontal (technological) way assumed planetary dimension.

American (USA) - Russian (Soviet Union) ideological confrontation was, in the same time, a competition not only in research and production of more and more sophisticated weapons, but - and first of all - in control over the space. To that effect, they made tremendous efforts in research on new materials and guiding systems needed for production and utilization of launching and orbital vehicles.

Results of this and other endeavours, especially in the fields of electronics, optoelectronic, computerizing and internet, spilled over into the civilian sector. Products made on the basis of high technologies (transistors, TV sets, mobile telephones, etc.) entered most homes and offices all around the world. Means of communications and other new technologies' products indicated transfer of the spirit of Industrial Revolution into spirit of Technological Revolution. Research on new materials, guidance and communication systems for military purposes gave a significant contribution to speeding up globalization ${ }^{3}$.

\section{Science and technology - Main engines of globalization}

Globalization is not a wave carried on across meadows and over horizons by some virtual force. Rather, it is a gradual process stemming from human activities in certain fields, such as science and technology, production and trade, communication and transportation, militarization and pacification etc.

The International Monetary Fund (IMF) identified four basic aspects/fields of globalization: trade and transportation; capital and investment movement; migration and

\footnotetext{
${ }^{3}$ Among scientists there are disputes regarding contributions of the military expenditures to the development. Some of them think they contribute to the employment and the economic growth, while the others think that military expenditures and military production break economic development. "Thus use of capital (for military purposes) produces parasitic economic growth", argues Seymour Malmen in his PENTAGON CAPITALISM The Political Economy of War, 1970.
} 
movement of people, and dissemination of knowledge. Environmental challenges, such as global warning, according to the IMF, are linked with globalization as well. All of them, and others, in interactions, embrace the Globe and modify its very nature.

It would be hard to specify which of the aspects precede the others and play a major role in globalization. All of them in interaction create globalization in its full scope. However, scientific discoveries and technological advances might be considered as major engines of globalization.

Today, new scientific discoveries, as a result of research, development and management, are being spread and promptly applied almost all over the world. Furthermore, they are the major driving force for speeding up globalization in economy and trade, communication and transportation, and in other aspects of globalization.

During the Industrial age, production of the technical goods was concentrated within developed countries, that is, the North-West area, while the underdeveloped world, that is South-East area used to be "market taker" and raw material "giver. Today, in new Technological age, sophisticated goods are being produced in most of the major developing states, which used to be "market taker" countries.

\section{Economic globalization and New International Economic Order}

Economic globalization, as we know it today, was shaped to a great extend at the end of the Second World War. The Bretton Woods Conference held even before the war ended, created three extremely important institutions: International Monetary Fund (IMF), the World Bank (WB), and the International Trade Organization (ITO), today often referred to as the Old International Economic Order (OIEO).

The OIEO was designed by the victorious allies, the dominant colonial powers of that era and it essentially served their interests. The Soviet Union refused to join the system and never did. Great majority of the UN member-states, specifically of the Third World countries, including China, has not recognized the Bretton Woods system and insisted on the need for it to be reformed. They tried to push through the General Assembly a concept of New International Economic Order (NIEO) but in vain. Nevertheless, in 1974, the General Assembly adopted a Declaration for establishment of such Order, as well as a "Program of Action" for its implementation, but it failed since "Western opposition completely killed it", as Ismail Serageldon ${ }^{4}$ said.

The Third World, or the Global South ${ }^{5}$ countries continued to insist on the need for the OIEO reforms, referring to the changes in the balance of the world power. To the verbal insistence, they added the establishment of new independent institutions creation of a group of five leading Global South states was established.

\footnotetext{
${ }^{4}$ See, Ismail Serageldon, "The Global South: The Next half Century", in the European Journal of Management and Public Policy, ECPD, Belgrade, 2015.

${ }^{5}$ In the professional literature one can encounter the term "Global South" (Global South" countries) instead of the "Third world" (the "Third world" countries), a geopolitical notion embracing almost whole Asia, Africa and South America, opposite to the Global North consisting od Europe, North Americas, Oceania and part of the Far East.
} 


\section{Globalization and demographic movements}

In the course of the evolving transition from the Industrial to the Technological age, dramatic changes were not only evident in the sciences and technologies, economy and trade, but they were also present in the human or demographic sphere as well.

The world population of about two billion people in 1927, increased to four billion in 1974, six billion in 1999, and 7 billion in 2011. It is estimated that in 2025 we will have about eight and in 2050 - almost 10 billion of the world population.

The world population growth accelerated along with the emergence and advancement of the technological revolution and globalization. At the same time, the migration of peoples also increased.

Migration of peoples is not something new. It is rooted deeply in history, leading back to the very origins of our species, but in the second half of the $20^{\text {th }}$ and at the beginning of the $21^{\text {st }}$ century it has been unprecedented. Inequality in the economic development and unrest in the world, numerous armed conflicts and foreign military interventions during the Cold War, dictated intensification of the human migration from the South to the North.

Booming economies of the Western European countries, in the middle of the $20^{\text {th }}$ century, provoked massive movement of the labour force from Southern Europe, Northern Africa and the Middle East to the Western Europe. Very soon, however, the Mediterranean Sea became the most dangerous border for the North African peoples in their way towards South-western Europe and further.

However, unrests in the North African and the Middle East countries, foreign military intervention in Iraq and Libya, the Afghanistan and Syrian wars, organization and activities of international terrorist groups have intensified migration of peoples dramatically from those areas towards the Western European countries. Only in 2015, till beginning of September, more than 380.000 peoples crossed the Mediterranean Sea and at least 2,850 drowned or went missing at sea in search for safety and a better life ${ }^{6}$. Recently, more than 60 per cent of them have landed in Greece tracing their ways to the Western European countries through the Balkan states. Today, millions of people are flowing from the South-east to the North-west in search not only for a job and better a life, but for safety as well, bringing serious problems to the receiving countries ${ }^{7}$.

On the other hand, population in Africa and the Middle East is rapidly growing, while population in Europe and across northern Asia is set to decline and get older. So this migration could be considered as some kind of balancing, but it is far beyond a normal process.

\footnotetext{
${ }^{6}$ According to Thakif Deen, the military conflicts and political instability, driving hundreds of refugees into Europe were triggered largely by the USA and Western military intervention for regime change, specifically in Iraq, Afghanistan and Libya, ISA, Other News, Sept. 4, 2015.

7 "From recently, they are moving across borders and sees in growing numbers, accepting great risks and placing strains on nations that receive them", is stated in the U.S. National Military Strategy, DoD Washington, D. C, May 2015.
} 


\section{Wider political globalization?}

Technological, economic and cultural globalization could be considered natural globalizations. They are crossing barriers, national and other borders without support of force. However, it is not the same with the political globalization, which is understood as the common world with common values imposed and dominated by the world leading power(s).

In the Western mass-media, political globalization is not widely published. It seems that journalists, political and other analysts try to avoid these sensitive questions since the pretenders to the world political leadership use it to impose their models of civilization by force.

During the Cold war there were two philosophies or ideologies: the Western democracy and Eastern dictatorship - each struggling to run the world. The Western democracy prevailed and the United States, supported by major European powers, as victors in the Cold War, tried to spread its own model of democracy to the whole world.

Political globalization, namely, is understood as a united world with a governing leader, meaning the Western values with the Western leadership. However, the contemporary world is too complex. Consisting of several civilizations, with deep historical traditions, it is more inclined to have clashes8, than living together in peace and harmony.

\section{Lack of global governance}

Long ago, especially during and just after the Great War, a lack of global governance was perceived. To fill that gap, on 10 January 1920 the League of Nations, an intergovernmental organization, was founded.

The League of Nations was the first international organization whose principal mission was to maintain peace through collective security. After a number of notable successes, the League of Nations proved to be unable to prevent aggressions by the Axis powers.

In the course of the Second World War, the League of Nations lost its credibility and existence. After that War, another international organization - the United Nations - was founded. The purposes of the United Nations were similar (or almost the same) as the principal roles of the League of Nations - "To maintain international peace and security, and to that end, to take effective collective measures for the prevention and removal of threats to the peace..." The responsibility for peace and security was trusted to the UN Security Council, while other matters of global significance were trusted to the General Assembly.

Through its activities on disarmament, prevention of the nuclear weapons proliferation, peacekeeping enforcement etc., the United Nations contributed significantly to preventing a big war, but it was unable to prevent a hundred small - local and regional wars. Besides, the United Nations have not made any significant steps towards the establishment of a New International Economic Order. Today, the principal UN missions are being undertaken by leading world power(s) more and more.

\footnotetext{
${ }^{8}$ See, Samual P. Huntinmgton, the Clash of Civilizations - Remaking of World Order, A Touchstone Book, New York, 1996.

${ }^{9}$ See, Charter of the United Nations, Art. I.
} 
Downfall of the UN. The UN's decline in performing its principal missions was gradual, but the main turning point was the Summit of Heads of states held in Cancun (Mexico) on 24 October 1981. The Summit was devoted to such issues as: how to grow more food, how to produce more energy, how to reduce trade barriers, etc.

It was expected that the Summit would turn down the Bretton Wood system in favour of the new international economic order but the outcome was quite the contrary. The USA and the UK were represented by newly elected President Ronald Reagan and British Prime Minister Mrs Margaret Thatcher respectively. Their policy prevailed with a great impact upon further development.

During that meeting, President Reagan paid little significance to the Third World demands and stated that he could not let the USA be equal to some other country. He also said publicly that the USA will decide when to use or not use the UN. Further along, Washington followed its policy as the nation with an exceptional destiny, trying to impose its own policy on the United Nations. His state-point that poverty generates poverty and the wealth generates wealth, it seems, prevailed as well.

\section{The American global leadership}

Promoting the US National Security Strategy of 2015, President Obama said: "Any successful (US) strategy must begin with an undeniable truth - America must lead"10 (bolded by T.M.) He also stressed that the question was not whether America would lead, but "how we will lead the world into the future". In the US National military strategy it is indicated why, how, and with whom America will lead.

First and foremost, America will lead with purpose (bolded by T.M.) - which is "grounded in American enduring national interests." America will lead with strength represented in the most dynamic and resilient economy and unrivalled military strength, but most of all with American founding values. America will lead by example, expressed in democratic institutions in the American governance. America, it is stated further, will lead with capable partners (and allies) - the cornerstone of American international engagement.

America is, no doubt, the most powerful country in the world. It has the strongest economy and non to second military. It holds a leading role in the unique military-political alliance and has a significant influence in the European Union and beyond ${ }^{11}$. However, the balance of the world power is changing. New economic and military powers are emerging and US global position relatively declines ${ }^{12}$. Besides, whether America has the skill, legitimacy and commitment to continue playing a leading role has been questioned from many sides. For example, a rather long time ago (in 2007), Russian President Vladimir Putin noted that concentration of decision authority in one country would not be sustainable.

\footnotetext{
${ }^{10}$ See, the White House paper on the National Security Strategy, February, 2015.

${ }^{11}$ According to David Vine, the U.S. dominate the world not only through the economic power and political influence, but through its military power as well. Hundreds of the U.S. bases and hundreds thousands of U.S. troops still encircle the Globe. (See, IPS, Other News, September 15, 2015.

12 "The USA-EU are declining not only as markets, also us producers", said Johan Galtung, founder and the first director of the Peace Research Institute, Oslo (PRIO), in his report on "The Real Global South Today: BRICS. See, Proceedings of the Ninth ECPD International Conference, Belgrade, October 20-21, 2012, ECPD, Belgrade, 2013.
} 


\section{Globalization and the World order: Towards bi-polarity}

The World order could be uni-, bi-, or multi-polar. This polarity is changeable, depending on the balance of the world power. In recent history we have witnessed all three modality multi-polarity between the two world wars; bi-polarity during the Cold War, and uni-polarity after the Cold War. Today, we are at the crossroad - to bi-, or to multi-polarity.

The uni-polar world order, with the USA as a centre of gravity, became questionable with the emergence and development of the Technological age. Born in the West, high technology has been rapidly transferred to the East, where it met with the huge quantity of inexpensive, industrious labour. Development and production of sophisticated goods and services was no longer a privilege of highly developed countries. Skilfully applied, the high technology, including modern management, resulted in emerging of, at first, the small, and later the "Big Asian Tigers". People's Republic of China with one billion, 250 million of inhabitants became leader of new developing world.

China and India with enormous labour force, Russia and Brazil, with huge natural resources and South Africa, the strongest African economy joined together in an un-formal organization ${ }^{13}$ known as BRICS. Its original aim was to counter G-7/G-8 in global monetary and economic policy, but during the course of development, it is becoming more and more a global political forum. At the periodical meetings, the BRICS members define their current policies and activities, primarily in extension cooperation with all developing countries.

Recently, in the world literature one can encounter the term "Global South", opposite to the "Global North" (Johan Galtung, Vijay Prashad, and others). It is not only geographic; it is more of a geo-political term. It includes Asia, Africa, Central and South America, while the Global North consists of Europe, without European Russia, North America, and Australia with some parts of Asia.

Central point of the Global South is China and of the Global North - USA. Numerous indicators show that the actual world order - still with many uni-polar characteristics, is going towards bi-polarity, quite different then bi-polarity of the Cold war. The alternative could be multi-polarity in case that the major players at the Great Chessboard decide to play their own games.

\section{Globalization and armament}

Armament, defined as "all the military forces and war equipment of a country"14 (or of the world) is part of human society and shares its destiny. It is global in scope, but in a specific way. It is global more than any other human aspect; armament is spread all around the world. Today, out of 193 UN-member states, only two countries (Costa Rika and Island) do not have armed forces. All other countries maintain their own military and try to keep them ready for war.

\footnotetext{
${ }^{13}$ There is no (or unknown) an official agreement on their establishment and function.

${ }^{14}$ More specific, military personnel, weapons and military equipment, resources (money and infrastructure) devoted to military purposes, etc.
} 


\section{Global Firepower}

Global Firepower (GFP) as a term means the same as the global military power. It consists of the military personnel (in the active and reserve duties), weapons and military equipment, and materiel resources (money, first of all) devoted to military purposes. Here, only military manpower and military spending are taken into considerations, with a reflection on the military technologies.

The GFP is not a static one; it is changeable, depending upon the international situation. At the end of the Cold War, for example, there were 28.6 million persons in the world on active military duty. Ten years later, that number felt to 22.3 million, and now we have about 21 million of the world military manpower.

Decrease of the military manpower was primarily due to technological advances. At the end of the $20^{\text {th }}$ and at the beginning of the $21^{\text {st }}$ century, big and powerful states, first of all the USA, introduced new hardware in their armed forces, developed on the new technological bases. At the same time, a group of military thinkers in Pentagon, led by Prof. Alvin Toffler, defined new strategy for the Electronic Warfare. They indicated that the Industrial model of warfare - concentration of huge quantities of armoured and artillery forces on the battlefields, was over ${ }^{15}$. They renamed the term "theatre" and extended it to "combat space" - a visual zone of action".

This strategy, also called Strategy XXI (for the $21^{\text {st }}$ century) requires less manpower than the strategy of the Industrial age. Tested in numerous wars waged by the US and coalition forces, it has been proved that this strategy requires less military manpower and quantity of weapons than the strategy defined by Von Clausewitz and others.

\section{New weapons for new Global strategy}

Military strategy defined by Von Clausewitz and other military thinkers was a strategy for the Industrial age. It required large troops concentrated on the battlefield divided between enemies by a front line. Major military operations were carried out on the land and at seas, supported by the fire power from air.

Strategy for the $21^{\text {st }}$ century, however, is conceived quite differently. Land troops concentration on battlefield is reduced or even eliminated in favour of the air power. Instead of huge quantities of artillery and armoured troops, Strategy XXI requires such firepower as: laser guided small arms weapons; guided mortar munitions; cannonlaunched guided projectiles, fired from artillery pieces, ship cannons and armoured vehicles; guided rockets and bombs - all together named Precision Guided Weapons, or Direct Attack Munition (PGW/DAM).

So-called Stand-off Weapons (SoW) and their platforms have particular significance. They are launched from land, from sea and undersea, from air and from space, against

\footnotetext{
${ }^{15}$ See Gordon R. Sullivan and James M. Dubic, War in the Information Age, Military Review, 74(1994), pp. 46 - 62.

${ }^{16}$ See, Morris J.Boyd and Michael Woodgerd, Information Operations - Force XXI Operations, Military Review, November 1994, pp. $16-28$.
} 
targets hundreds miles/kilometres away. Such weapons were tested in the Gulf War (Operation "Desert storm"), further improved and used in several other wars, including NATO aggression against FR Yugoslavia. Newest versions of such weapons are nonpiloted vehicles, controlled from Nevada, launched from Afghanistan against targets in Pakistan, for example. Recently, big powers (the USA, Russian Federation and China) have adopted new military strategies, confirming their decisions to continue with strengthening their military potentials.

The strategy for $21^{\text {st }}$ century and corresponding weapons have been developed by big powers, first of all by the USA. Small and less developed countries are not able to develop and produce precession guided or stand-off weapons. However, they could be (and have been) attacked by them, without the capability to respond adequately.

\section{Global military sending}

Military spending represents rather heavy burden on the economy of each country. Its volume depends upon international situation. During the Cold War, the two super powers and two military blocks used to spent tremendous amounts of money for military purposes. The Third World countries did not lag too far behind them.

At the end of the Cold War, the global military spending reached almost US $\$ 1,000$ billion. (967 billion in 1989). However, after call-ups of the USSR and the Warsaw pact disintegration, military spending of this group of countries was dramatically reduced. The USA and other NATO countries, having lost their major enemy, reduced their military expenditures as well, but not in such a large scale.

The last decade of the $20^{\text {th }}$ century was the only one after the Second World War in which the military spending (the military manpower as well) was reduced. From $\$ 967$ billion in 1989, the world military spending came at the level of $\$ 760$ billion ten years later $^{17}$. However, the reduction of the military spending did not last too long. With the entrance in the $21^{\text {st }}$ century, the global military spending began to rise.

Due to its engagement in the Afghanistan, and later on in the Iraq war, the USA increased its military budget. Russia and China began to increase their military spending as well. So, in 2004 , the global military expenditure significantly surpassed those from 1989 , reaching the amount of $\$ 1.361$ billion. It continued to rise and in 2013 it was estimated to have been $\$ 1.747$ billion, representing 2.4 per cent of global gross domestic product (GDP) or $\$ 248$ per each person of the world. It was 26 per cent higher than in 2004 , while a share of global GDP, that is the global military burden, remained stable. More than 60 per cent of total world military expenditures is spent by five biggest military spenders, while ten largest military spenders expended about 70 per cent of total world military budgets (Table 1).

\footnotetext{
${ }^{17}$ Major reductions were made by big powers. The Soviet Union's armed forces of 5,096,000 in 1989, were reduced to 1,654,000 in 1973 of all Independent. Commonwealth States (Russian 964,000). Peoples Republic of China reduced its armed forces from 3,500,000 in 1989 to 2,250,000 in 1998, while the United States' armed forces were decreased from $2,163,000$ to $1,450,000$ in the same period of time. (Data from the MILITARY BALANCE, annual editions).
} 
The World's Globalization and Global Militarization

Table 1 - Ten biggest military spenders (2013)

\begin{tabular}{|l|r|r|r|}
\hline \multicolumn{1}{|c|}{ Country } & Spending (\$ bn) & \multicolumn{1}{c|}{ Share of GDP (\%) } & \multicolumn{1}{c|}{ World share (\%) } \\
\hline USA & 640.0 & 3.8 & 37.0 \\
\hline China & 188.0 & 3.0 & 11.0 \\
\hline Russia & 87.0 & 4.1 & 5.0 \\
\hline Saudi Arabia & 67.0 & 9.3 & 3.8 \\
\hline France & 61.3 & 3.3 & 3.5 \\
\hline United Kingdom & 57.9 & 2.3 & 3.3 \\
\hline Germany & 48.8 & 1.9 & 2.8 \\
\hline Japan & 48.6 & 1.0 & 2.8 \\
\hline India & 47.4 & 2.5 & 2.7 \\
\hline South Korea & 33.9 & 2.8 & 1.9 \\
\hline Total & $\mathbf{1 , 2 8 0 . 0}$ & & $\mathbf{7 3 . 8}$ \\
\hline
\end{tabular}

(SIPRI Yearbook, 2014, p. 182)

Despite the significant reduction of the world military manpower and hardware quantity, the world military spending increases. It is due to high costs of research, development and production of weapons, requested by the military strategies designed for the new electronic warfare.

\section{Global arms transfers}

The trend of the global arms transfers (international arms trade) is going along with the trend of the global military expenditures. From early 1980s, the volume of the arms transfers was in downfall trend almost constantly until 2000 - 2004, when it was only 44 per cent of the volume in $1980-1984$. Over the past ten years, according to SIPRI Yearbook, it has been increasing. In $2004-2008$ it was 14 per cent higher than in previous five years' period and continued to rise until 2012/2013.

In the global arms transfers, the major suppliers and receivers are easily recognized. The major suppliers are big powers and big arms producers, while the receivers are primarily developing countries. Today, the five largest suppliers are: the USA, Russia, Germany, China, and France. China, India and some other countries are both - suppliers and receivers.

The global arms transfer does not represent some significant financial value. However, it does have important economic and political dimensions. The export of arms and military equipment, military technologies, and military engineering, is considered to be the most lucrative business. On the other side, the arms import imposes serious economic burden to the receivers.

Besides the military importance, the arms transfer has political significance, as well. The big powers, as a rule, deliver the arms and military technologies primarily to their own allies and friendly counties. In case they export them to some neutral states, they expect to achieve some political benefits and/or to extend military cooperation with the recipient. 


\section{Global arms race}

Arms race represents competition between two or more countries or military coalitions in possessing and strengthening military power. In the eve of the Great War, it was conducted between a group of states preparing for aggression, on the one, and the other European powers, on the other side. It was almost the same before the Second World War.

During the Cold War, the main participants in the arms race were two super powers, each supported by their own allies. With the call-ups of the Soviet Union and disintegration of the Warsaw pact, the arms race ended. However, the USA continued to maintain strong military power, but without a partner to compete with in running the arms race.

In the beginning of the $21^{\text {st }}$ century, new regional powers emerged, threatening American leadership in each aspect of globalization, including military. Russia recovered its economy, reorganized and reequipped its military, and re-established rough nuclear parity with the USA, while China, along with its rapid economic growth, intensified modernization of its armed forces.

After withdrawal from Iraq in 2011, the USA began to reduce its military spending, but the funds devoted to research, development and procurement of new weapons remained very high (almost $\$ 200$ billion each year). The slices of Russia's and China's military budgets devoted to the research and development are also significant.

Today's arms race is heading primarily towards the horizontal (technological) direction. In the programs of research and development of the big powers priority is given to the so called "smart" weapons and precision guided munition. Research and development of the ballistic weapons is significantly reduced in favour of the smart weapons capable to attack targets hundreds miles/kilometres far from the launching sites.

Now we have a new round of the arms race with different participants. The USA convincingly leads and it probably will be leading for a longer time. However, Russia and China amplifying additional energy try to approach the USA in quantity as well as in quality of the military hardware.

Big powers are paying special attention to research and development of the so-called non-lethal weapons. In the US National Military Strategy, for example, special attention has been given to defence of the cyber-attacks. It could be presumed that the USA at the same time also develops offensive weapons of this kind. Western news agencies reported that Russian troops or Russian supported rebels in eastern Ukraine use so-called electronic weapons to jam, cancel and/or incapacitate Ukraine's and NATO's communications ${ }^{18}$.

Arms race conducted by the big powers, especially in development and use the Stand-off and Direct-attack weapons brings small and less developed countries in very difficult position. They are indirectly involved in that race and enforced to spend considerable part of their GDPs for military purposes without possibility to develop or to supply such weapons or to provide means needed for effective defence in case they are attacked by such weapons.

\footnotetext{
${ }^{18}$ The USA plans to spend 800 billion of US dollars for research and development in next ten years, while Russia for the same purpose and the same period of time is planning to spend 20 trillion of rubles (\$364 billion) for purchasing "high tech weapons.
} 


\section{Global nuclear threat}

It is widely recognized that nine states - the USA, Russian Federation, the United Kingdom, France, China, India, Pakistan, Israel and North Korea - possess nuclear weapons of estimated 16,950 warheads. This overall quantity of nuclear warheads, according to the SIPRI Yearbook 2014, is declining primarily due to Russian-USA agreements on the nuclear weapons control and/or reduction.

Both countries try to compensate for the reductions of the existing nuclear arsenals by modernization of the existing, and research, development and production of new nuclear weapons. The USA Government, for example, plans to spend $\$ 350$ billion to maintain and modernize its nuclear forces in the next ten years. This includes, inter alia, designing a new class of submarine with ballistic missiles (SSBM), a new strategic bomber, the next generation of land based intercontinental ballistic missile (ICBM) and others.

Reduction of Russian nuclear strategic forces is due to gradual retirement of all Sovietera missiles, which are being replaced by new modern systems. Modernization of its strategic forces is also motivated by the intention to maintain rough nuclear parity with the USA.

The nuclear arsenals of the other nuclear-armed states are considerable small, but all of them are engaged in developing or deploying new nuclear weapons. Some of those countries have announced their intentions to do so. China, India, North Korea and Pakistan are the only nuclear weapon states that are expanding their nuclear arsenals. Israel is considered as a nuclear weapons state, but it has neither denied nor confirmed their possession.

Table 2 - World nuclear forces (January 2014)

\begin{tabular}{|c|c|c|c|c|}
\hline Country & $\begin{array}{l}\text { Year of first } \\
\text { nuclear test }\end{array}$ & $\begin{array}{l}\text { Deployed } \\
\text { warheads }\end{array}$ & $\begin{array}{c}\text { Other } \\
\text { warheads }\end{array}$ & $\begin{array}{c}\text { TOTAL } \\
\text { Inventory }\end{array}$ \\
\hline United States & 1945 & 2.100 & 5.200 & 7.300 \\
\hline Russia & 1949 & 1.600 & 6.400 & 8.000 \\
\hline United Kingdom & 1962 & 160 & 65 & 225 \\
\hline France & 1960 & 290 & 10 & 300 \\
\hline China & 1964 & - & 250 & 250 \\
\hline India & 1974 & - & $90-110$ & $90-110$ \\
\hline Pakistan & 1998 & - & $100-120$ & $100-120$ \\
\hline Israel & & - & 80 & 80 \\
\hline North Korea & 2006 & - & & $6-8$ \\
\hline Total & & 4.150 & 12.200 & 16.350 \\
\hline
\end{tabular}

(Source: SIPRI Yearbook 2014)

Nuclear weapons are spread all around the world: on the land ${ }^{19}$, at the sea and under the sea, and in the air (mounted on the strategic bombers). Nevertheless, the likelihood of a global nuclear war is significantly reduced, but it is not the same with regional wars.

\footnotetext{
${ }^{19}$ In Europe.
} 
The situation in the Far East, South Asia, or Middle East - all of them nuclear-armed regions, warns about a possibility of a nuclear war. Besides, several other countries Argentina, Brazil, South Africa, Iran, Libya (late Gadhafi's intentions) - have expressed their desire to possess nuclear weapons. Possession and use of nuclear weapons by powerful terrorist groups is not far from reality.

\section{Global terrorism}

Terrorism, as an act of destruction and violence, is not new. It has been used since the early times of recorded history. However, the modern terrorism of international or global dimensions, has largely taken its shape at the turn of the $20^{\text {th }}$ century. Although it has recently attracted broad international attention, it would be relatively hard to define its meaning ${ }^{20}$.

Perpetrators of terrorism are individuals, groups and/or states. A modern trend in terrorism appears to lead towards loosely organized, self-financed, international networks. .A state can sponsor terrorism by funding and allowing proving grounds in its territory to the terrorist groups. A state can also be an organizer and perpetrator of terrorism.

The aim of individuals or minor terrorist groups is usually to provoke attention of public opinion on their existence and purpose. Larger terrorist activities, however, could be undertaken with an economic, religious, political or ideological goal.

Al-Qaeda was the most powerful and best organized terrorist group. Its attacks against US key economic and defence centres were largest terrorist endeavour ever undertaken and achieved. The USA responded by setting for George Bush's "Anti-terror" strategy which lead to the Afghanistan war and killing its leader Osama bin Laden. Later on, in February 2015, promoting the new US National Security Strategy, president Barak Obama said "Even as we have decimated Al-Qaeda's core leadership, more diffused networks of Al-Qaeda, ISIL ${ }^{21}$, and affiliated groups threaten US and international security" and announced decision to "degrade and destroy" Sunni extremist groups in the Middle East, the ISIL being the main targeted group.

Terrorism has become a global "evil empire", threatening almost everyone, everywhere, which should be fought by all available means.

\section{Global and regional security}

After dramatic geopolitical changes at the end of 1980 s and the very beginning of the 1990s, several indicators suggested that the world is going towards positive development in maintaining and strengthening international peace and security. The threat of big nuclear war declined and the overall desire to build a new world order increased.

\footnotetext{
${ }^{20}$ In professional literature has been described variously as both a tactic and strategy, a crime and a holy duty, a justified reaction to oppression. Obviously, it depends on whose point of view is being represented.

${ }^{21}$ ISIL, Islamic State of Iraq and Levant.
} 
However, the things did not go that way. The likelihood of a new world war diminished, but many new local wars (internal violence, inter states conflicts, foreign military interventions) emerged. The Gulf War (Operation "Desert Storm"); Yugoslav inter-ethnic and inter-religious wars ended with the NATO aggression on Serbia: terrorists attacks on the key American economic and defence centres; Afghanistan and Iraq wars; Arabs springs - these are only a few of such terrible events of the last twenty five or so years.

The world is facing several regional crises which could escalate into global dimensions. The armed conflicts in the Middle East threaten to break the regional borders, while peoples' migration from that area and the North Africa could create a deep European crisis. The increasing tension between the USA and Russia threatens to return the world in a new cold war. The Western Balkan peoples still have not found the way to reconcile, fifteen years after the inter-ethnic and inter-religious wars, while the tension between two Far-eastern states of the same origin tends to escalate in an open armed conflict. Now it seems, unfortunately, that the world is still far from achieving anything that could be described as "global peace".

\section{Concluding Remarks}

Globalization is an inevitable process. It is going along with the human society's development. Science and high technologies are its major driving force, being unmistakable engines for the fast economic growth and cultural advances.

Globalization is impacting almost every aspect of human life. It is changing even the man and his way of life. The very nature is also being changed under globalization's processes. The strongest globalization's impact is extended upon the economy and relations among peoples and states - "market taker" and raw material "giver". Sophisticated goods are now manufactured in and exported from numerous, until recently developing states. However, the gap between the highly developed North and underdeveloped South still exists and, more importantly, the gap between the rich and the poor all around the world is deepening.

The trend of deepening the gap between the rich and the poor provokes unrest on one and fiery reactions of the rich and powerful (recent and current events in Afghanistan, Iraq, Libya, Syria) with far reaching negative consequences (mass migration for example). That might be one of the reasons of sharp differences among proponents and opponents of globalization.

Mr Staples' opinion might be rather extreme, but it is a fact that more wars were waged after than during the Cold War. Economic inequality is growing; more conflicts and civil wars are emerging. Human migration unprecedented in the modern time presses Europe and threatens to bring its disintegration. Let me here cite one of the opponents of globalization, saying: "Globalization promotes the conditions that lead to unrest, inequality, and ultimately to war" (Mr Steven Staples, Chair of the International Network on Disarmament and Globalization, Vancouver, Canada).

In the process of globalization, the world military power was not reduced. Quite the contrary: we are now facing a new round of arms race and the world is heading towards a new cold war. Current crisis, local and regional armed conflicts threaten to escalate in a big war. 
Proponents of globalization are inclined to say that current issues are transitory. True globalization with western values fully implemented has not been completed. When completed, the world will live in peace, security and welfare. However, is the selected way leading towards achieving that end the best way? It should be noted that the Jeans, Coca Cola, fast food chains, pop music and the like have made greater western influence and global promotion than all those political pressures and military interventions.

\section{Literature/sources}

[1] What is globalization?, DoD Executive summary, Washington, D.C. March, 2015.

[2] Relationship between globalization and militarism, by Steven Staples, Social justice.

[3] Magazine, Vol. 27, No. 4 (2000).

[4] Seymour Melman, Pentagon capitalism, Washinton, DC, 1970.

[5] Samuel Huntington, The Clash of Civilization, A Tachstone Book, New York, 1996.

[6] Andrew J. Goodpaster, When diplomacy is not enough - Managing multinational.

[7] Military intervention, Carnegie Commission, July 1996.

[8] Gordon Sallivsan and James M. Dubic, War in the Information age, Military Review, 74(1994).

[9] Morris J. Boyd and Michael Woodgerd, Information operations - Force XXI, Military.

[10] Review, November 1994.

[11] What is Information warfare?, National Defence University, Washington, DC,1995.

[12] The Information and Communication revolution, The European Journal of Management and Public Policy, Volume 12 - No. 2 (2011).

[13] SIPRI Yearbook 2014.

[14] The Law of war and dubious weapons, SIPRI, 1974.

[15] Todor Mirkovic, Strategije $i$ ratne doktrine supersila $i$ blokova (Strategies and Military doctrines of the super powers and military blocks), VIZ, Belgrade, 2003.

[16] Johan Galtung, The Real Globalization - South today, Proceedings of the Ninth ECPD International conference, Belgrade, 3 October, 2013.

[17] Reshaping the International Order, A Report to the Clab of Rome, 1979.

[18] Idriss Jazairy, Towards Global Convergence - The evolving role of the Global South, The European Journal of Management and Public Policy, Vol.123 - No.1 (2013.)

[19] Paolo Acanfora, The Global South in the New International Disorder - The Idea of Shared Society, The European Journal of Management and Public Policy, Vol.123 - No.1 (2013).

[20] Wikipedia, the Free Encyclopaedia. 